\title{
Altered intestinal epithelium-associated lymphocyte repertoires and function in $\mathrm{Apc}^{\mathrm{Min} /+}$ mice
}

\author{
LORRAINE MARSH ${ }^{1}$, P. LOUISE COLETTA ${ }^{2}$, MARK A. HULL ${ }^{2}$, PETER J. SELBY ${ }^{3}$ and SIMON R. CARDING ${ }^{1,4}$ \\ ${ }^{1}$ Institute of Molecular and Cellular Biology, University of Leeds, Leeds LS2 9JT; ${ }^{2}$ Leeds Institute of Molecular Medicine, \\ Wellcome Trust Brenner Building, ${ }^{3}$ Cancer Research UK Clinical Centre, St. James's University Hospital, Leeds LS9 7TF, UK
}

Received June 23, 2011; Accepted July 28, 2011

DOI: 10.3892/ijo.2011.1176

\begin{abstract}
A p c^{M i n /+}$ mice spontaneously develop multiple intestinal adenomas along the length of the small intestine and colon. Currently little is known about the role of the immune system in regulating intestinal tumorigenesis in these animals. This study characterised small intestinal intraepithelial lymphocyte (IEL) populations in C56BL/6J $\mathrm{Apc}^{\mathrm{Min} / \mathrm{+}}$ mice and wild-type $\left(\mathrm{Apc}^{+/+}\right)$mice. We also determined the effect that $\mathrm{T}$ cells expressing either $\gamma \delta$ or $\alpha \beta$ encoded T cell receptors (TcR) exert on intestinal tumorigenesis. $A p c^{M i n /+}$ mice had significantly lower numbers of $\mathrm{CD}^{+}$IELs compared with $\mathrm{Apc}^{+/+}$littermates and displayed reduced cytotoxicity against tumour target cells. Further analysis of IEL cytotoxicity revealed differences in the cytotoxic pathways utilised by IELs in $A p c^{\mathrm{Min} /+}$ and $\mathrm{Apc}^{+/+}$ mice with $A p c^{M i n /+}$ IELs displaying an absence of perforin/ granzyme-mediated killing and increased levels of Fas-FasLmediated cytotoxicity compared with wild-type IELs. Analysis of $A p c^{\mathrm{Min} /+}$ mice crossed with $\alpha \beta$ T-cell deficient $\left(\mathrm{TcR} \beta^{--}\right)$or $\gamma \delta$ T-cell deficient $\left(\mathrm{TcR}^{--}\right)$mice on the same genetic background revealed decreased tumour multiplicity in the absence of both $\alpha \beta$ and $\gamma \delta$ T-cells. This study demonstrates that altered T-cell subsets play important roles in promoting tumorigenesis in $A p c^{M i n /+}$ mice and forms the basis for future mechanistic studies.
\end{abstract}

\section{Introduction}

C57BL/6J Apc ${ }^{M i n /+}$ mice carry a heterozygous point mutation in the Adenomatous polyposis coli (Apc) tumour suppressor gene resulting in a truncated protein lacking $\mathrm{C}$-terminal domains $(1,2)$. Apc is a negative regulator of the Wnt signalling pathway with loss of Apc function leading to dysregulated transcription of Wnt/ß-catenin target genes (3). Wnt signalling governs cell differentiation and fate in many different tissues including $\mathrm{T}$ and B cells (4). Apc $c^{M i n /+}$ mice spontaneously develop intestinal adenomas following loss of the second Apc allele $(1,5)$ and have

Correspondence to: Professor Simon R. Carding, ${ }^{4}$ Present address: The Institute of Food Research and The University of East Anglia, Norwich Research Park, Norwich NR4 7UA, UK

E-mail: simon.carding@bbsrc.ac.uk

Key words: tumorigenesis, Min mouse, intraepithelial lymphocytes IEL cytotoxicity, adenoma been used extensively to identify genetic factors affecting intestinal tumorigenesis, (6,7) such as Mom-1 (8), Mom-2 (9), Mom-3 (10), Mom-7 (11) and cyclin D1 (12). Little, however, is currently known about the immune system in the $\mathrm{Apc}^{\mathrm{Min} /+}$ mouse and its role in intestinal tumorigenesis. Early studies involving beige (13) and scid mice (14) suggested that NK, T and B cells had no effect on intestinal tumour formation and progression. However, the latter study was performed using scid mice on a C57BL/6 background known to be leaky, allowing some mature lymphocytes to develop, which may have been sufficient for tumour suppression to occur at a level equivalent to $\mathrm{C} 57 \mathrm{Bl} / 6 \mathrm{Apc} \mathrm{Min} /+^{-}$ mice. Several studies have suggested roles for the immune system in tumour surveillance including supplementation of diet with Sc-FOS, an indigestible carbohydrate that promotes bacterial growth in the colon $(15,16)$ and stimulates gut-associated lymphoid tissues, which was associated with reduced colonic tumour multiplicity (17). This tumour-suppressive effect was subsequently shown to be dependent on the presence of T-cells (18) and IL-15 secretion (19).

Regulatory $\left(\mathrm{CD} 4{ }^{+} \mathrm{CD} 25^{+}\right)$lymphocyte populations have been shown to have differing effects in colon cancer models either by inhibiting anti-tumour surveillance activities or by suppression of inflammation and tumour prevention (20). In $\mathrm{Apc}^{\mathrm{Min} /+}$ mice, addition of $\mathrm{CD} 4^{+} \mathrm{CD} 25^{+}$lymphocytes has been shown to reduce tumour multiplicity in the small intestine and colon (21).

Intraepithelial lymphocytes (IEL) reside between epithelial cells in the small intestine and are thought to contribute to epithelial homeostasis and barrier function $(22,23)$. IELs are predominantly $\mathrm{CD} 8^{+} \mathrm{T}$-cells (24) with $>20 \%$ expressing CD4 (25). Features that distinguish IELs from other T-cell populations are that they contain a greater number of $\gamma \delta$ T-cells with the majority of $\mathrm{CD} 8^{+}$IELs expressing a CD8 $\alpha \alpha$ homodimer that is virtually absent among circulatory $\mathrm{CD} 8^{+}$ T-cells (25). Based upon differences in phenotype and antigen recognition IELs can be divided into two types; type a $\alpha \beta$ IELs are associated with recognition of antigens presented by conventional MHC class I and II molecules and express a $\mathrm{CD} 8 \alpha \beta$ heterodimer. Type b CD8 $\alpha \alpha^{+} \alpha \beta$ and $\gamma \delta$ IELs which respond to non-MHC-restricted antigens (26) and are capable of recognising molecules expressed on stressed and transformed epithelial cells (27-29), including Rae-1 and H-60 in mice (30). The immunological function of IELs in general is unknown (23) and conflicting evidence has been obtained for 
the involvement of $\gamma \delta$ T-cells in tumour surveillance $(31,32)$. Kettunen et al (33) analysed small intestine lymphocytes from $A p c^{M i n /+}$ mice and found no difference in the number of CD8 ( $\alpha \alpha$ and/or $\alpha \beta$ ) T-cells per villus compared with $A p c^{+/+}$. However, this study made no attempt to distinguish between the IELs and T cells within the underlying lamina propria. To address the role of local T-cell populations in intestinal tumorigenesis, we analysed IELs in $A p c^{\mathrm{Min} /+}$ and wild-type mice and determined the impact of the absence of $\alpha \beta$ and $\gamma \delta$ T-cell subsets on intestinal tumorigenesis.

\section{Materials and methods}

Animals. All animals were purchased from The Jackson Laboratory (Bar Harbor, ME, USA) and were bred and housed at the University of Leeds according to institutional and UK Home Office guidelines. All animals were housed in isolators under SPF conditions. Genotyping of mice was performed on genomic DNA (GenElute ${ }^{\mathrm{TM}}$, Sigma-Aldrich, Dorset, UK) by ARMS-PCR (34) using Jumpstart ${ }^{\mathrm{TM}}$ REDTag $^{\mathrm{TM}}$ Readymix $^{\mathrm{TM}}$ (Sigma-Aldrich). Female $T c R \delta^{-/-}$(B6.129P2-Tcrd $\left.{ }^{\text {tm1Mom }}\right)$ and $T c R \beta^{-/-}\left(\mathrm{B} 6.129 \mathrm{P} 2-\mathrm{Tcrb}^{\mathrm{tm} 1 \mathrm{Mom}}\right)$ mice were bred with male C57BL/ $6 \mathrm{~J}-A p c^{M i n /+}$ mice to produce the following genotypes: $A p c^{M i n /+}$ $T c R \delta^{-/}, A p c^{+/+} T c R \delta^{-/-}, A p c^{M i n /+} T c R \beta^{-/-}, A p c^{+/+} T c R \beta^{-/-}, A p c^{M i n /+}$ $T c R \delta^{+/+} T c R \beta^{+/+}\left(A p c^{M i n /+}\right)$ and $A p c^{+/+} T c R \delta^{+/+} T c R \beta^{+/+}\left(A p c^{+/+}\right)$. Individual genotypes were confirmed at weaning and again at the time of sacrifice.

Adenoma size and multiplicity. At 120 days of age, animals were sacrificed and the entire small intestine and colon were removed, flushed with PBS and mesentery removed. The small intestine was divided into proximal, middle and distal regions with each being examined in a blinded manner using a dissecting microscope. The largest diameter of each tumour and number of tumours present were recorded for each section. A two-tailed power calculation performed using an average total adenoma count of 51.2 (34) established a test population size of 13 animals being required to detect a $50 \%$ difference in adenoma number in the test groups. All adenoma counts were performed in a blinded manner and all initial counts and measurements were confirmed by a second person to confirm accuracy.

Immunohistochemistry. Tissues were fixed in $4 \%(\mathrm{w} / \mathrm{v})$ paraformaldehyde (Sigma-Aldrich) and embedded in paraffin wax. Longitudinal sections $(6 \mu \mathrm{m})$ were cut using a microtome, mounted on SuperFrost Plus microscope slides (BDH) and stained with H\&E. Prior to immunohistochemistry, sections were subjected to antigen retrieval (Antigen Unmasking Solution; Vector, Peterborough, UK) and endogenous peroxidase and avidin-biotin activity was blocked using standard protocols. Tissues were then sequentially incubated with a rat anti-mouse CD3 antibody (1:100, Serotec), biotinylated anti-rat antibodies (1:200, Vector), streptavidin-horseradish peroxidase (Vector), diaminobenzidine substrate, and hematoxylin. $\mathrm{CD}^{+}$IELs were counted from a minimum of 10 villi per sample along the entire crypt-villus axis. CD3 ${ }^{+}$IEL counts were performed blinded to animal genotype.

IEL isolation. IELs were isolated from Peyer's patch-excised small intestine (35). For cytotoxicity assays higher purity preparations of IELs were obtained using a modification of a previously described method (36). Briefly, the mucosal layer of small intestine was removed by scraping and then dissociated in RPMI-1640 containing 10\% (v/v) HI-FCS and $10 \mathrm{mM}$ dithioerythritol. Cell debris was removed using a $0.7-\mu \mathrm{m}$ cell strainer (BD Biosciences) and single cell suspensions were passed over two glass wool columns (Sigma-Aldrich), after which the cells in the effluent were subjected to Percoll density gradient centrifugation. IELs were harvested at the 40-80\% interface and cell number and viability assessed by haemocytometercounting and trypan blue dye exclusion.

Flow cytometry. IELs were stained with a combination of the following monoclonal antibodies: Per-cyP anti-CD3 (1452C11, BD Biosciences), FITC-anti-TcR $\gamma \delta$ (GL3 Fab ${ }_{2}$, Caltag Medsystems),-CD4(RM4-5,Caltag) and-CD45(30-F11,Caltag), PE-anti-CD8 $\alpha$ (CT-CD8a, Caltag), -Fas (Jo2, BD Biosciences) and -FasL (MFL3, BD Biosciences), APC-anti-Thy-1 (5a-8, Caltag) and -NKG2D (CX5, BD Biosciences) or, biotin-antiTcR $\alpha \beta$ (H57-597, Caltag) -CD8 $\beta$ (CT-CD8b, Caltag) or $\alpha-N K 1.1$ (PK136, Caltag) followed by streptavadin-AF633. Background levels of non-specific staining were determined using isotypematched control antibodies. Samples were analysed using FACSCalibur (Becton-Dickinson) and Cellquest software (Becton-Dickinson).

Re-directed cytotoxicity assay. Cellular cytotoxicity was measured using a Live/Dead ${ }^{\circledR}$ cell assay (Molecular Probes, Leiden, The Netherlands) using the P815 murine mastocytoma cell line (ATCC, Teddington, UK). Briefly, $1 \times 10^{4}$ target cells were incubated with 3,3'-dioctadecyloxacarbocyanine (DiOC) then cultured with IELs at varying effector:target cell ratios (0:1 to $100: 1)$ both in the presence and absence of $\alpha$-CD3 (145-2C11) for $4 \mathrm{~h}$ at $37^{\circ} \mathrm{C}$ in round-bottomed 96-well plates (Bibby Sterilin, Stone, Staffordshire). Prior to analysis by flow cytometry, cells were incubated with propidium iodide (PI). Dead target cells $\left(\mathrm{PI}^{+}\right)$were identified as a proportion of total target cells. In some experiments, IELs were pre-incubated with either $1 \mu \mathrm{M}$ concanamycin A (CMA), $15 \mu \mathrm{g}$ anti-FASL antibody (Alexis Biochemicals, Lausen, Switzerland), or control mouse IgG.

Statistical analysis. Statistical testing for differences between $A p c^{+/+}$and $A p c^{M i n /+}$ mice was performed using non-parametric Mann-Witney U tests. Statistical differences between small intestine regions were calculated using a non-parametric Kruskal-Wallis $\mathrm{H}$ test. Statistical testing for differences in adenoma penetrance in $A p c^{\mathrm{Min} /+}$ mice of different genotypes was performed using Chi-square analysis. All statistical analyses were carried out using Statistical Package for the Social Sciences (SPSS, Surrey, UK). Values of $p<0.05$ were considered statistically significant with different levels of significance indicated as follows; ${ }^{*} \mathrm{p}<0.05,{ }^{* *} \mathrm{p}<0.01$ and ${ }^{* * *} \mathrm{p}<0.005$. Unless specified, all data are expressed as the mean and standard error of the mean (SEM).

\section{Results}

A survey of IEL phenotype was carried out at 40 and 100 days of age prior to and after macroscopic tumour development, respectively. Mice (120-day-old) were used for intestinal 

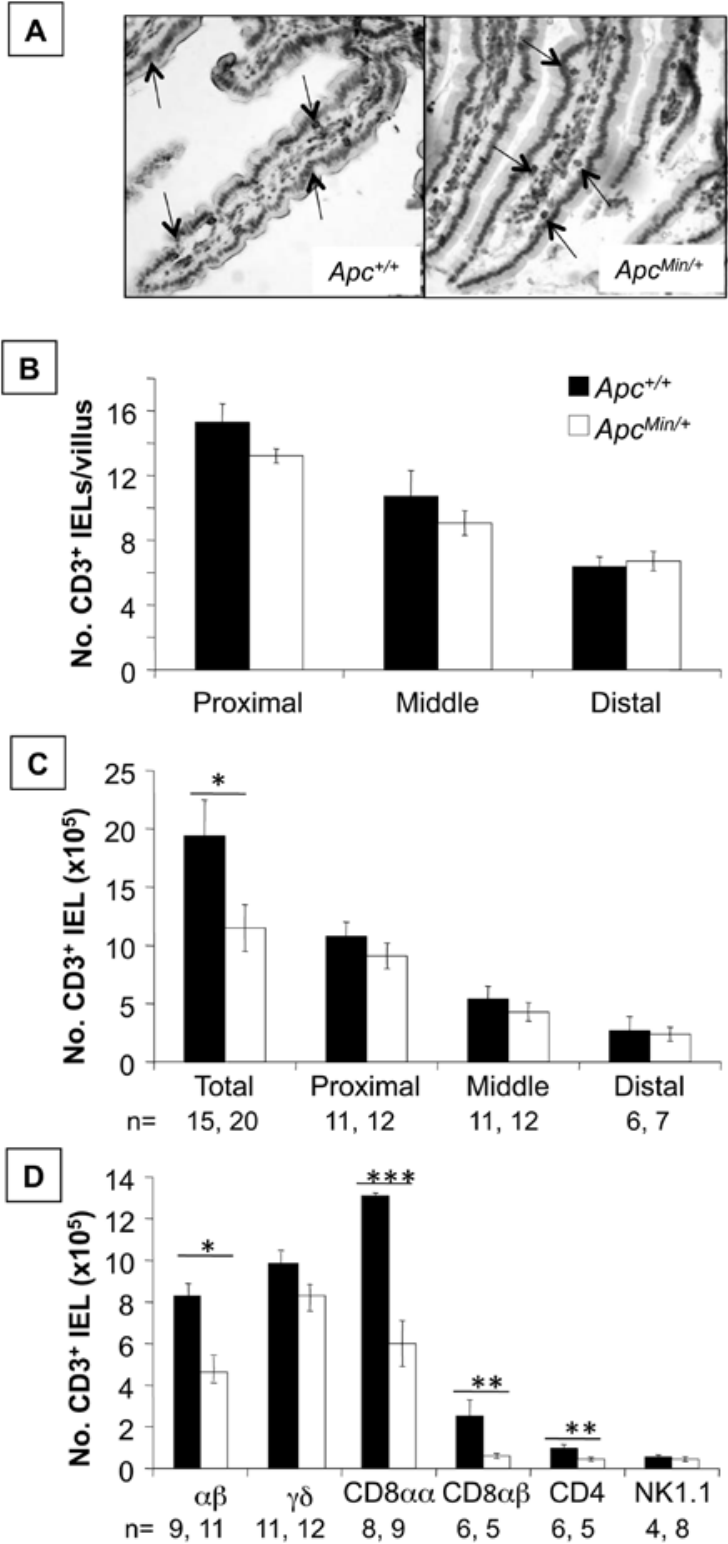

Figure 1. Altered distribution of IELs in $\mathrm{Apc}^{\mathrm{Min} / \mathrm{+}}$ mice. (A) Sections of proximal small intestine from 40-day-old $\mathrm{Apc}^{+/ /}$and $\mathrm{Apc}^{\mathrm{Min} /+}$ mice were stained with anti-CD3 antibodies and counterstained with haematoxylin to visualise IELs in the boundary epithelium (arrows). (B) The number of IELs per villus in different regions of the small intestine of 40-day-old $\mathrm{Apc}^{+/+}$and $\mathrm{Apc}^{\mathrm{Min} /+}$ mice was determined by counting blind a minimum of 10 villi per section from 4-5 sections per mouse and a minimum of 5 mice of each genotype. The data shown represent the mean \pm SEM. (C) Total number of IELs in different regions of the small intestine of 100-day-old $\mathrm{Apc}^{+/+}$and $\mathrm{Apc}^{\mathrm{Min} /+}$ mice was determined by staining isolated IELs with anti-CD45 and CD3 antibodies and flow cytometric analysis and electronically gating on and counting $\mathrm{CD}^{4} 5^{+}, \mathrm{CD}^{+}$IELs. The data shown represent the mean \pm SEM values with the $n$-values shown below the $\mathrm{x}$-axis representing the number of animals used to obtain each data set. ${ }^{*} \mathrm{p}<0.05$. (D) The phenotype of IELs in 100-day-old $\mathrm{Apc}^{+/+}$and $\mathrm{Apc}^{\mathrm{Min} /+}$ mice was determined by staining isolated IELs with anti-CD3 and TcR $\alpha \beta$ or $\mathrm{TcR} \gamma \delta$ antibodies in conjunction with $\mathrm{CD} 4, \mathrm{CD} 8 \alpha / \beta$ or NK1.1 antibodies and three-colour flow cytometric analysis. The data represent the mean \pm SEM number of $\mathrm{CD}^{+}$IELs that co-express different TcRs and surface antigens with the $n$-values representing the number of animals used of each strain to obtain the data sets. ${ }^{* *} \mathrm{p}<0.01,{ }^{* * * *} \mathrm{p}<0.005$.

phenotype analysis as this time point allowed for maximal macroscopic tumour formation and quantitation prior to
Table I. Distribution of IEL subsets in 40-day-old $\mathrm{Apc}^{+/+}$and $\mathrm{Apc}^{\mathrm{Min} / \mathrm{t}}$ mice.

\begin{tabular}{lll}
\hline Cell surface marker & $\mathrm{Apc}^{+/+}$ & $\mathrm{Apc}^{\mathrm{Min} /+}$ \\
\hline IEL No. $\times 10^{5}$ ( \pm SEM) & & \\
TcR $\alpha \beta$ & $6.17 \pm 1.11$ & $3.18 \pm 0.62$ \\
TcR $\gamma \delta$ & $5.44 \pm 0.72$ & $3.74 \pm 0.69$ \\
CD8 $\alpha \alpha$ & $13.1 \pm 0.14$ & $6.00 \pm 1.10$ \\
CD8 $\alpha \beta$ & $2.51 \pm 0.79$ & $0.60 \pm 0.12$ \\
CD4 & $0.97 \pm 0.19$ & $0.45 \pm 0.09$ \\
NK1.1 & $0.55 \pm 0.11$ & $0.45 \pm 0.11$ \\
$\gamma \delta$ IEL No. x $10^{5}( \pm$ SEM $)$ & & \\
CD8 $\alpha$ & $5.7 \pm 0.78$ & $2.91 \pm 0.65$ \\
Fas & $4.03 \pm 0.62$ & $2.68 \pm 0.63$ \\
Thy-1 & $1.32 \pm 0.58$ & $1.09 \pm 0.22$ \\
FasL & $1.41 \pm 0.41$ & $1.22 \pm 0.18$ \\
NKG2D & $0.10 \pm 0.03$ & $0.62 \pm 0.40$ \\
\hline
\end{tabular}

the onset of intestinal and extraintestinal complications that result in premature death around 150 days of age in $A p c^{M i n /+}$ mice (1).

Altered IEL populations in Apc $c^{\text {Min/+ }}$ mice. Immunohistochemistry and flow cytometry were used to compare the distribution of IELs in $\mathrm{Apc}^{+/+}$and $\mathrm{Apc}^{\mathrm{Min/+}}$ mice. Sections of proximal, middle and distal small intestine from 40-day-old mice were stained with anti-CD3 antibody (Fig. 1A) and $\mathrm{CD}^{+}$IELs were counted in at least 10 complete crypt-villus axes per mouse and from 5 mice per group (Fig. 1B-D). Along the proximaldistal axis of the small intestine the number of IELs/villus in $\mathrm{Apc}^{+/+}$and $A p c^{\mathrm{Min} /+}$ mice were comparable (Fig. 1B), as reported previously for $\mathrm{Apc}^{+/+}$mice (25). However, there was a trend towards reduced numbers of IELs/villus in $\mathrm{Apc}^{\mathrm{Min} /+}$ mice compared with wild-type mice in the proximal and middle regions (Fig. 1B).

By 100 days of age, the number of $\mathrm{CD}^{+}$IELs in $\mathrm{Apc}^{\mathrm{Min} /+}$ mice $\left(11.5 \pm 3.1 \times 10^{5}\right)$ was significantly lower than in $A p c^{+/+}$ mice $\left(19.4 \pm 31 \times 10^{5}, \mathrm{p}<0.05\right)$ (Fig. 1C). This difference was not attributable to regional differences in IELs between the two strains of mice with similar numbers being present in the proximal, middle and distal regions of $\mathrm{Apc}^{+/+}$and $\mathrm{Apc}^{\mathrm{Min} /+}$ mice (Fig. 1C). By comparison, the numbers of CD3 intraepithelial leukocytes (primarily B cells and NK cells) were not significantly different in $\mathrm{Apc}^{\mathrm{Min} /+}$ and $\mathrm{Apc}^{+/+}$mice (data not shown).

More detailed characterisation of IEL populations revealed that $A p c^{M i n /+}$ mice contained significantly fewer TcR $\alpha \beta^{+}$IELs $\left(3.18 \pm 0.6 \times 10^{5}\right)$ compared with $A p c^{+/+}$mice $\left(6.17 \pm 1.1 \times 10^{5}\right)$ at 100 days of age $(\mathrm{p}<0.05)$ (Fig. 1D and Table I). In addition, there was a $>2$-fold reduction in the number of CD8 $\alpha \alpha^{+}\left(\mathrm{Apc}^{+/+}\right.$ $\left.13.1 \pm 0.14 \times 10^{5}, A p c^{\mathrm{Min} /+} 6.0 \pm 1.0 \times 10^{5} ; \mathrm{p}<0.005\right)$ and $\mathrm{CD} 4^{+}\left(\mathrm{Apc}^{+/+}\right.$ $\left.0.97 \pm 0.19 \times 10^{5}, A p c^{M i n /+} 0.45 \pm 0.01 \times 10^{5} ; \mathrm{p}<0.01\right)$ IEL subsets and a $>4$-fold decrease in $\mathrm{CD} 8 \alpha \beta^{+}\left(A p c^{+++} 2.51 \pm 0.79 \times 10^{5}, A p c^{\mathrm{Min} /+}\right.$ $\left.0.61 \pm 0.12 \times 10^{5} ; \mathrm{p}<0.01\right)$ IELs in $A p c^{M i n /+}$ mice compared with $\mathrm{Apc}^{+/+}$mice (Fig. 1D). By comparison, the number of NK1.1 $1^{+}$ NK T cells IELs in $A p c^{+/+}\left(0.55 \pm 0.11 \times 10^{5}\right)$ and $A p c^{M i n /+}$ mice $\left(0.45 \pm 0.11 \times 10^{5}\right)$ were similar (Fig. 1D). 
In contrast to the reduced number of TCR $\alpha \beta$ IELs in $A p c^{M i n /+}$ mice (Fig. 1D) the number of TcR $\gamma \delta^{+}$IELs recovered from $A p c^{M i n /+}$ mice $\left(3.74 \pm 0.69 \times 10^{5}\right)$ was lower but not significantly different from that in $A p c^{+/+}$mice $\left(5.44 \pm 0.72 \times 10^{5}\right)$ (Fig. 1D). There were however differences in the composition of TCR $\gamma \delta$ IELs in $A p c^{M i n /+}$ mice, which contained significantly fewer CD $8 \alpha \alpha^{+} \mathrm{TcR} \gamma \delta^{+}$IELs $\left(2.91 \pm 0.65 \times 10^{5}\right)$ compared to 100-day-old $\mathrm{Apc}^{+++}$mice $\left(5.70 \pm 0.78 \times 10^{5} ; \mathrm{p}<0.05\right)$ (Fig. 2A). By contrast, the proportion of TCR $\gamma \delta^{+}$IELs expressing the activation-associated antigens, Fas, Thy-1 or FasL were equivalent in $\mathrm{Apc}^{+/+}$and $\mathrm{Apc}^{\mathrm{Min} /+}$ mice at 100 days of age (Fig. 2A). Although the number of TcR $\gamma \delta^{+}$IELs expressing NKG2D in $\mathrm{Apc}^{+/+}$mice was 2.7-fold higher than in $\mathrm{Apc}^{+/+}$mice (Fig. 2) this increase was not significant. $\gamma \delta$ IEL repertoire analysis using available anti-TcR-variable $(\mathrm{V} \gamma / \delta)$ region-specific antibodies revealed similar profiles of $\mathrm{V} \gamma$ and $\mathrm{V} \delta$ chain usage among TcR $\gamma \delta$ IELs in 100-day old $\mathrm{Apc}^{+/+}$and $\mathrm{Apc}^{\mathrm{Min} /+}$ mice with $\mathrm{V} \gamma 7^{+}$cells predominating with smaller populations of $\mathrm{V} \gamma 1^{+}, \mathrm{V} \gamma 4^{+}, \mathrm{V} \gamma 5^{+}, \mathrm{V} \delta 4^{+}$ and V86.3 $3^{+}$cells (Fig. 2B). RT-PCR analysis for all known functional $\mathrm{V} \gamma$ and $\mathrm{V} \delta$ chains was consistent with the flow cytometric analysis (Fig. 2B) with equivalent levels of expression of $\mathrm{V} \gamma 1,2,4,5$ and 7 and $\mathrm{V} \delta 2-8$ with very low or no detectable expression of $\mathrm{V} \delta 1$ and $\mathrm{V} \gamma 6$ transcripts in both strains of mice (data not shown). The spectratypes of PCR-derived $\mathrm{V} \gamma$ transcripts expressed among IELs from $\mathrm{Apc}^{\mathrm{Min} /+}$ and $\mathrm{Apc}^{+/+}$ mice were compared to identify any structural differences in the CDR3-regions of individual receptors. Analysis of the predominant $\mathrm{V} \gamma 7$ receptor revealed identical profiles of CDR3 regions with two major fragments of 186 and 189 bp (Fig. 2C). Collectively, these findings demonstrate that $\mathrm{Apc}^{\mathrm{Min} /+}$ mice have significantly fewer IELs than their $A p c^{+/+}$siblings, which can be attributed to reduced numbers of both $\mathrm{CD} 4^{+}, \mathrm{CD} 8 \alpha \beta^{+}$ (type a) IELs and CD8 $\alpha \alpha^{+} \alpha \beta$ IELs and CD8 $\alpha \alpha^{+}$(type b) $\gamma \delta$ IELs.

Decreased adenoma number in the small intestine of Apc $c^{\text {Min/t+ }}$ mice lacking $T c R \alpha \beta^{+}$or $T c R \gamma \delta^{+} T$ cells. To determine whether the altered T-cell populations contributed to tumorigenesis male $A p c^{M i n /+}$ mice were crossed with female C57BL/6-R $\mathrm{AG}^{-/}$, $-T c R \delta^{-/}$or $-T c R \beta^{-/-}$mice. Although $A p c^{\mathrm{Min} /+} T c R \beta^{-/-}$and $A p c^{\mathrm{Min} /+}$ $T c R \delta^{-/-}$colonies were readily established it was not possible to obtain sufficient numbers of $A p c^{M i n /}{ }^{R A G}{ }^{-/}$mice for analysis. At 120 days of age adenomas were measured and counted in the intestine of $A p c^{M i n /+} T c R \delta^{+/+} T c R \beta^{+/+}\left(A p c^{M i n /+}\right), A p c^{M i n /+}$ $T c R \delta^{-/}$and $A p c^{\mathrm{Min} /} T c R \beta^{-/-}$mice. Adenoma number in the small intestine was significantly reduced by 79 and $48 \%$ in $A p c^{M i n /+}$ $T c R \beta^{-/-}$mice $(16.7 \pm 3.6)$ and $A p c^{\mathrm{Min} /+} T c R \delta^{-/-}$mice $(40.3 \pm 10.7)$, respectively, compared to wild-type, $\left(\beta^{+/+} \delta^{+++}\right), A p c^{M i n /+}$ mice $(77.7 \pm 4.7 ; \mathrm{p}<0.001)$ (Fig. 3A). It was also noted that two $T c R \beta^{-1-}$ $A p c^{M i n /+}$ animals and one $T c R \delta^{-/} A p c^{M i n /+}$ animal failed to develop any adenomas by 120 days (data not shown).

As reported previously $(37,38)$, the number of adenomas increased along the proximal-distal axis of the small intestine in $A p c^{\mathrm{Min} /+}$ mice (proximal $=8.31 \pm 1.1$, middle $=22.1 \pm 2.6$, distal $=46.31 \pm 3.1 ; \mathrm{p}<0.001)$, which was also seen in $A p c^{M i n /+} T c R \delta^{-1-}$ mice (proximal $=6.1 \pm 1.1$, middle $=12.37 \pm 4.7$, distal $=18 \pm 4.9$; p <0.005) (Fig. 3B). TcR $\beta^{-1-} A p c^{M i n /+}$ mice however had comparable and low numbers of adenomas along the proximal-distal axis of the small intestine (5.49 \pm 1.32 ) (Fig. 3B). TcR $\beta^{-/}$and $T c R \delta^{-1} A p c^{M i n /+}$ mice had significantly fewer adenomas in
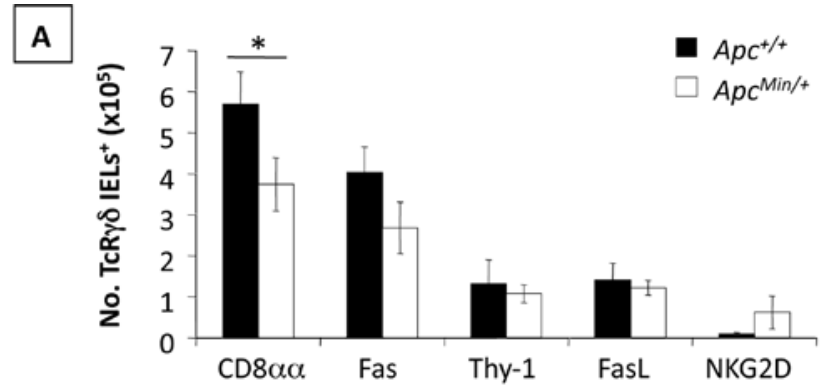

B
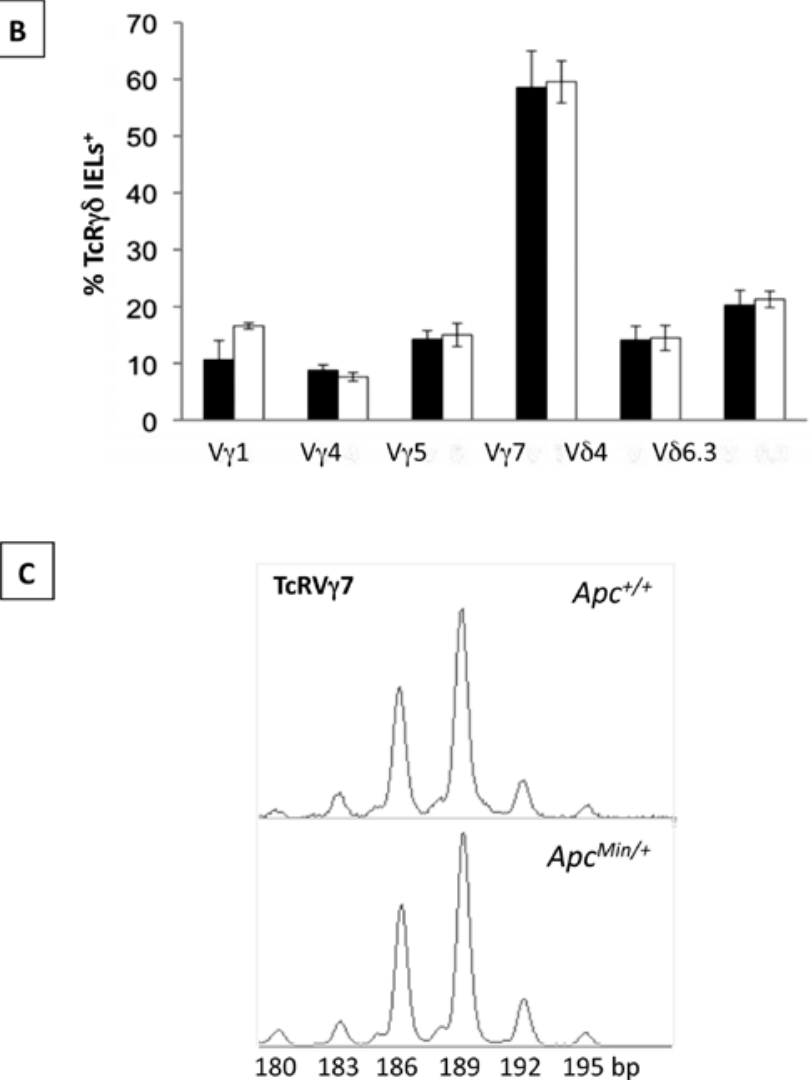

Figure 2. Altered $\gamma \delta$ IEL repertoires in $\mathrm{Apc}^{\mathrm{Min} /+}$ mice. (A) The composition of TcR $\gamma \delta^{+}$IELs in 100-day-old $\mathrm{Apc}^{+/+}$and $\mathrm{Apc}^{\mathrm{Min} /+}$ mice was determined by staining isolated IELs with anti-CD3 and TcR $\gamma \delta$ antibodies in conjunction with anti-Fas, Thy-1, -FasL and -NKG2D antibodies and three-colour flow cytometry. The data represent the mean \pm SEM values obtained from 6-9 mice of each strain. ${ }^{*} \mathrm{p}<0.05$. (B) TcR-V $\gamma / \delta$ usage among $\gamma \delta$ IELs in 100-day-old $\mathrm{Apc}^{+/+}$ and $\mathrm{Apc}^{\mathrm{Min} /+}$ mice was determined by staining isolated IELs with anti-CD3 and $T c R \gamma \delta$ antibodies in combination with antibodies specific for different $\mathrm{V} \gamma$ and $\mathrm{V} \delta$ receptor chains. The data represent the mean \pm SEM values obtained from the analysis of at least 7 mice of each strain. (C) Spectratype analysis of $\mathrm{V} \gamma 7 \mathrm{TcRs}$ expressed by IELs in 100-day-old $\mathrm{Apc}^{+/+}$and $\mathrm{Apc}^{\mathrm{Min} /+}$ mice. The profiles show the size distribution (in base pairs) of PCR-amplified CDR3 regions of $\mathrm{V} \gamma 7 \mathrm{TcR}$ chains expressed by $\mathrm{V} \gamma 7^{+}$IELs that identifies two prominent-sized receptors of 189 and $186 \mathrm{bp}$ in both strains of mice $(\mathrm{n}=6$ each).

all regions of the small intestine compared to $A p c^{M i n /+}$ mice (p $<0.05$ for all groups; Fig. 3B). There were also inter-strain differences in adenoma distribution in the small intestine with $T c R \beta^{-/} A p c^{M i n /+}$ mice having significantly fewer adenomas in both the middle and distal small intestine compared to $T c R \delta^{-1}$ $A p c^{M i n /+}$ mice (p<0.05; Fig. 3B).

For all genotypes the size of adenomas in the middle $\left(A p c^{\mathrm{Min} /+}=2.1 \pm 0.03, A p c^{\mathrm{Min} /+} \mathrm{TcR} \delta^{-/}=2.1 \pm 0.05, A p c^{\mathrm{Min} /+} \mathrm{Tc} R \beta^{-/-}\right.$ 


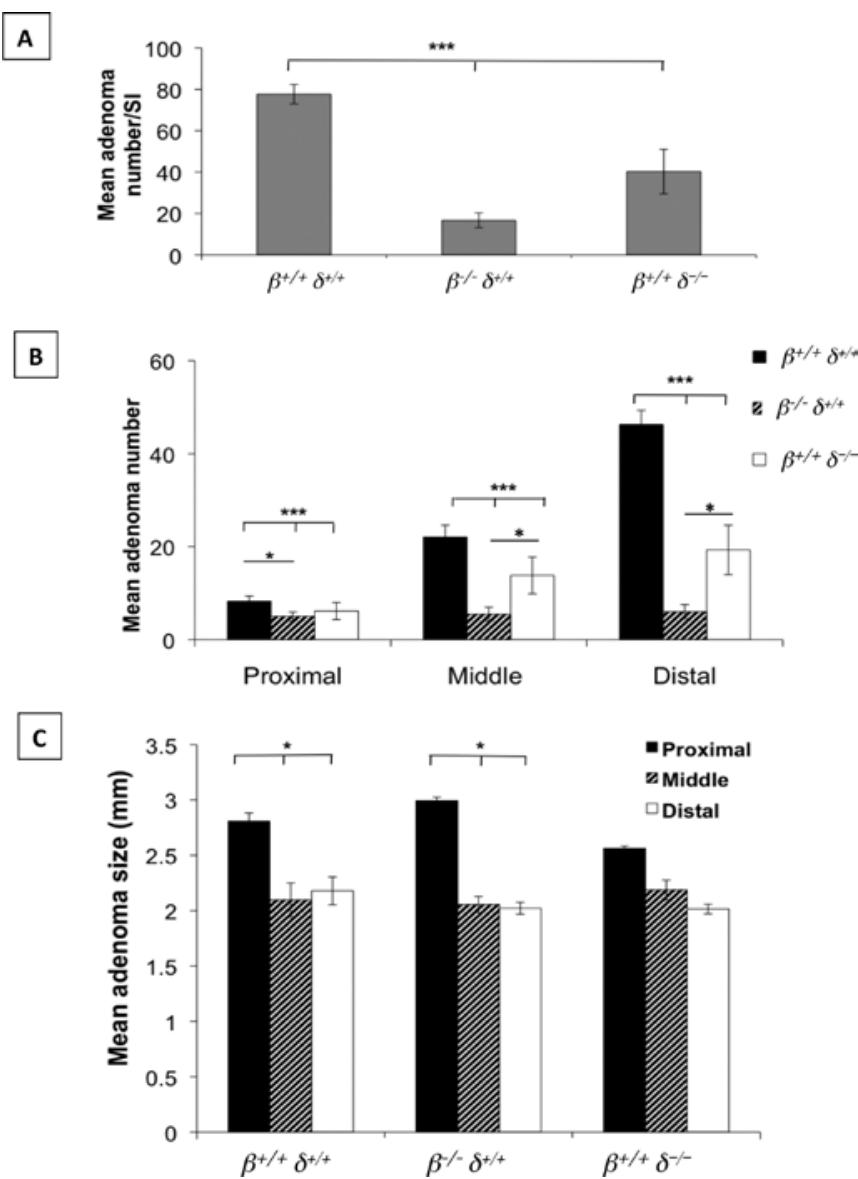

Figure 3. Reduced tumour formation in $\gamma \delta$ or $\alpha \beta \mathrm{T}$ cell-deficient $\mathrm{Apc} \mathrm{Min} /+^{\mathrm{M}}$ mice. (A) The total number of adenomas present in the small intestine of 120-dayold T cell replete $\mathrm{Apc}^{\mathrm{Min} /+}$ mice $\left(\beta^{+/+} \delta^{+/+} ; 77.7 \pm 4.7\right)$ and $\mathrm{Apc}^{\mathrm{Min} /+}$ mice lacking either $\alpha \beta$ T cells $\left(\beta^{-/-} \delta^{+/+} ; 16.7 \pm 3.6\right)$ or $\gamma \delta$ T cells $\left(\beta^{+/+} \delta^{--/} ; 40.3 \pm 10.7\right)$ was determined using coded samples and by two individuals blinded to the coding. The data shown represent the mean \pm SEM number of adenomas present in each strain of mice $(\mathrm{n}=15-17) .{ }^{* * *} \mathrm{p}<0.005$. (B) Regional distribution of adenomas in the small intestine of 120-day-old $\mathrm{Apc}^{\mathrm{Min} /+}$ mice and $\mathrm{Apc}^{\mathrm{Min} /+}$ mice deficient of $\alpha \beta$ or $\gamma \delta$ T cells. " $p<0.05$. (C) Adenoma size was determined by measuring the diameter of adenomas present in different regions of the small intestine of 120-day-old $\mathrm{Apc}^{\mathrm{Min} /+}$ mice and $\mathrm{Apc}^{\mathrm{Min} /+}$ mice deficient of $\alpha \beta$ or $\gamma \delta \mathrm{T}$ cells with the data shown representing the mean \pm SEM values in each strain of mice.

$=2.1 \pm 0.07)$ and distal $\left(A p c^{M i n /+}=2.2 \pm 0.02, A p c^{M i n /+} T c R \delta^{-/-}=\right.$ $\left.2.0 \pm 0.04, A p c^{\mathrm{Min} /+} T c R \beta^{-/}=2.0 \pm 0.07\right)$ small intestine were comparable. In the proximal region adenomas were significantly larger in $A p c^{M i n /+}(2.8 \pm 0.1)$ and $A p c^{M i n /+} T c R \beta^{-/-}(2.9 \pm 0.15)$ than those in the middle or distal $(\mathrm{p}<0.005)$ region of the intestine (Fig. $3 \mathrm{C})$. An exception to this was in $A p c^{\mathrm{Min} / \mathrm{+}}$ mice lacking $\gamma \delta$ IELs where the increase in size of proximal adenomas (2.6 \pm 0.13$)$ compared to those in the middle and distal segments did not reach statistical significance (Fig. 3C). No significant difference was observed in the size of adenomas in the proximal, middle or distal small intestine in $A p c^{M i n /+}$ and $A p c^{M i n /+}$ strains lacking functional $\alpha \beta$ or $\gamma \delta$ T-cells (Fig. 3C).

Adenomas in the colon of Apc $c^{\text {Min/+ }}$ mice lacking $\alpha \beta$ and $\gamma \delta T$ cells. Penetrance of tumours in the colon varied between the different strains of $\mathrm{T}$ cell replete and deficient $A p c^{\mathrm{Min} / \mathrm{+}}$ mice. Approximately 88\% (14/16) of $A p c^{M i n /+}$ mice developed colonic adenomas whereas adenoma development within the colon of $A p c^{M i n /+}$ mice lacking functional $\alpha \beta$ T-cells was rare and

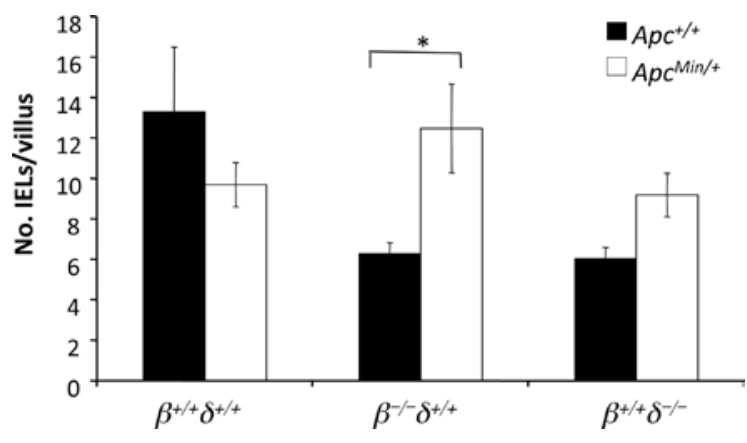

Figure 4. IEL numbers in $\mathrm{Apc}^{\mathrm{Min} /+}$ mice. Sections of the middle region of the small intestine from 120-day-old $\mathrm{Apc}^{\mathrm{Min} /+}$ mice $\left.\beta^{+/+} \delta^{+/+}, \mathrm{n}=16\right)$ and $\mathrm{Apc}^{\mathrm{Min} /+}$ mice deficient of $\alpha \beta$ T cells $\left.\beta^{-/-} \delta^{+/+}, n=15\right)$ or $\gamma \delta$ T cells $\left(\beta^{+/+} \delta^{-/}, n=17\right)$ were stained with anti-CD3 antibodies and the number of $\mathrm{CD}^{+}$IELs per villus was determined as described in the legend of Fig. 1 . The data represent the mean \pm SEM of $\mathrm{CD}^{+}$IELs per villus in the different strains of mice. " $\mathrm{p}<0.05$

significantly less than $A p c^{\text {Min/+ }}(2 / 15=13.3 \%$; $p<0.01)$. Of these one mouse developed one tumour whereas the other developed two tumours. The lack of colonic adenomas in the vast majority of these mice prevented any statistical analysis being performed. The occurrence of colon tumours was also significantly lower in $A p c^{\mathrm{Min} /+}$ mice lacking $\gamma \delta$ T-cells (5/17=27.8\%; $\mathrm{p}<0.05)$ compared to $A p c^{\mathrm{Min} /+}$ mice. There was also a trend for tumour-bearing $A p c^{M i n /+} T c R \delta^{-/-}$to have more colonic tumours than $A p c^{\mathrm{Min} /+}$ mice $\left(A p c^{\mathrm{Min} /+} T c R \delta^{-/-} \mu=2.8 \pm 0.49 ; A p c^{\mathrm{Min} /+}\right.$ $\mu=2.0 \pm 0.36$ ) although the difference was not significant. There were no differences in the size of colonic adenomas in any of the genotypes of $A p c^{\mathrm{Min} /+}$ mice (data not shown).

Increased IELs in Apc ${ }^{\mathrm{Min} /+}$ mice lacking $\alpha \beta$ T-cells. To identify differences in IEL populations that may contribute to adenoma development, quantitative analysis of IELs in $A p c^{M i n /+}$ mice deficient in either $\alpha \beta$ or $\gamma \delta$ T cells and IELs was performed. Longitudinal sections of middle small intestine from 120-dayold $A p c^{M i n /+}$ and $A p c^{+/+}$mice with normal T cell populations or that lacked $\alpha \beta$ or $\gamma \delta$ T-cells were stained with an anti-CD3 antibody and $\mathrm{CD}^{+}$IELs counted from at least 10 complete crypt:villus axes per mouse, from 5 or more mice per group. $A p c^{M i n /+}$ mice lacking functional $\alpha \beta$ T-cells $\left(A p c^{M i n /+} T c R \beta^{-/-}\right)$had a 2-fold increase in the number of $\mathrm{CD}^{+}$IELs/villus compared with $A p c^{+/+}$mice $(\mathrm{p}<0.05)$. By contrast, $A p c^{M i n /+}$ mice lacking $\gamma \delta$ T-cells $\left(A p c^{\mathrm{Min} /+} T C R \delta^{-/}\right)$had similar numbers of IELs per villus compared with $A p c^{+/+}$siblings (Fig. 4).

Reduced IEL cytotoxicity in Apc ${ }^{\mathrm{Min} /+}$ mice. Redirected cytolysis assays were used to quantitate IEL cytotoxicity among freshly isolated IELs from 40- and 100-day-old $\mathrm{Apc}^{+/+}$and $A p c^{\mathrm{Min} /+}$ mice. It was not possible to obtain enough IELs from mice $>40$ days of age to examine cytotoxicity prior to adenoma development. IELs from 40-day-old $A p c^{M i n /+}$ mice displayed significantly lower levels of killing of P815 target cells at a 10:1 effector:target cell ratio (by 27\%, p<0.05) than $A p c^{+/+}$IELs (Fig. 5A). This difference was also observed at lower effector:target cell ratios but was not statistically significant. By contrast, IELs isolated from 100-day-old $A p c^{M i n /+}$ mice (Fig. 5B) showed statistically significant reduced cytotoxicity at all effector:target ratios tested (by $33 \%$ at $10: 1, \mathrm{p}<0.05$; by $44 \%$ at $5: 1, \mathrm{p}<0.05$; by $53 \%$ 

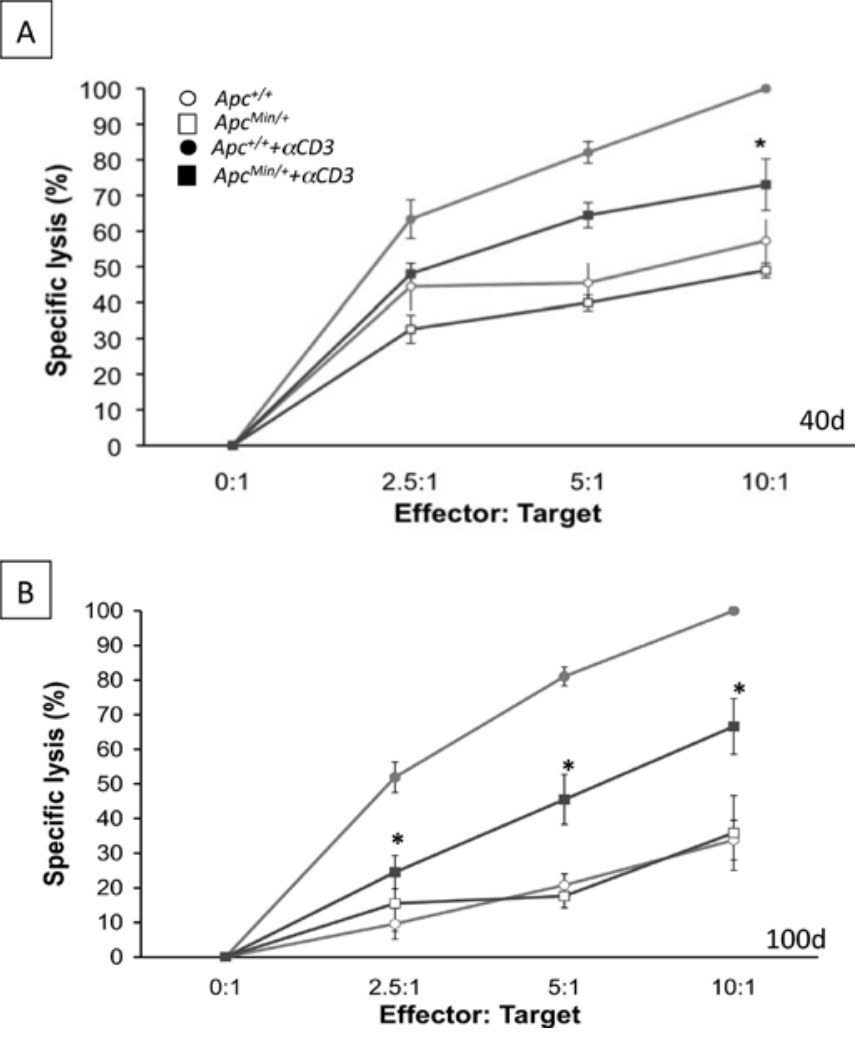

Figure 5. Reduced levels of IEL cytotoxicity in $\mathrm{Apc}^{\mathrm{Min} /+}$ mice. Effector IELs from individual 40- (A) or 100-day old (B) $\mathrm{Apc}^{+/+}$(red lines) and $\mathrm{Apc}^{\mathrm{Min} /+}$ (blue lines) mice $(\mathrm{n}=4$ each) were incubated with P815 target cells at various effector (E):target $(\mathrm{T})$ cell ratios in the absence or presence of anti-CD3 antibodies $(+\alpha C D 3)$ and $4 \mathrm{~h}$ later the proportion of dead versus live target cells determined by flow cytometry as described in the Materials and methods. The data shown represent the mean \pm SEM percent-specific lysis at different E:T ratios. ${ }^{*} \mathrm{p}<0.05$.

at 2.5:1, $\mathrm{p}<0.05)$. In the absence of anti-CD3 antibodies the levels of cytotoxicity among $A p c^{+/+}$and $A p c^{M i n /+}$ IELs were equivalent.

Altered mechanisms of killing among cytotoxic Apc $c^{\mathrm{Min} /+}$ IELs. To investigate the mechanisms of IEL killing redirected cytolysis assays were repeated in the presence of either concanamycin A (CMA) that blocks perforin-granzyme-mediated cytotoxicity or, neutralising anti-FasL antibodies to block Fas-FasL-mediated cytolysis. In the presence of CMA, specific lysis of target cells by $A p c^{+/+}$IELs was significantly reduced by $61.5 \pm 14.4 \%$ with some variation observed between individual animals. (Fig. 6A, p<0.05). By contrast, CMA had no significant effect on target cell killing by $A p c^{\mathrm{Min} /+}$ IELs (Fig. 6A). The reverse was observed using neutralising anti-FasL antibody, which significantly reduced target cell killing by $A p c^{\mathrm{Min} /+}$ IELs by $41.6 \pm 9.7 \%$ (Fig. 6B, p<0.05) whereas anti-FasL antibodies had no discernable effect on $A p c^{+/+}$IEL killing of the target cells (Fig. 6B). These findings are consistent with reduced levels of cytotoxicity among IELs in $\mathrm{Apc}^{\mathrm{Min} /+}$ mice and differences in the mechanisms by which target cells are killed.

\section{Discussion}

The close proximity of IELs to the epithelium in the small intestine makes them ideally suited for immunosurveillance. However, very little is known regarding the effect of IELs and
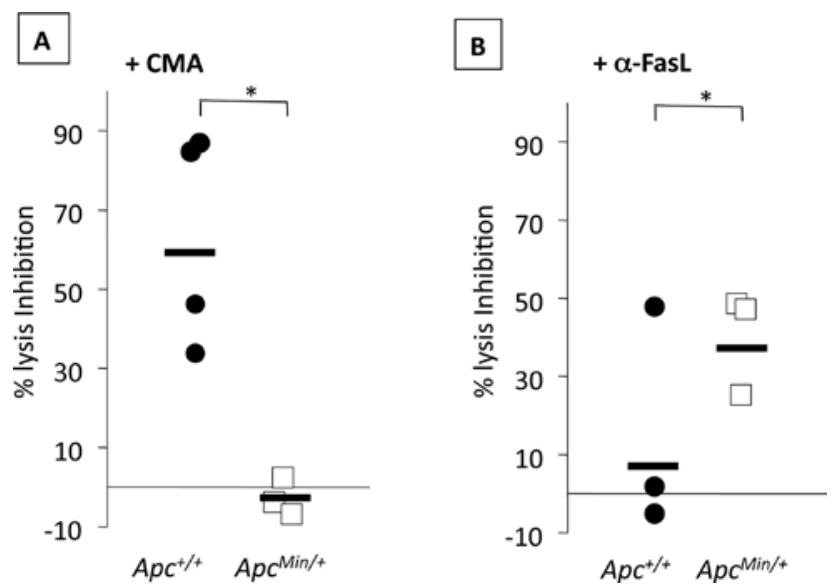

Figure 6. Altered pathways of IEL cytotoxicity in $\mathrm{Apc}^{\mathrm{Min} /+}$ mice. Effector IELs from individual 100-day-old $\mathrm{Apc}^{+++}(\mathrm{n}=3)$ and $\mathrm{Apc}^{\mathrm{Min} /+}$ mice $(\mathrm{n}=3)$ were preincubated with either $1 \mathrm{mM}$ concanamycin-A (CMA) or anti-FasL antibody $(\alpha$ FasL) for $1 \mathrm{~h}$ prior to culturing with P815 target cells (10:1, E:T) in the presence of anti-CD3 antibody for $4 \mathrm{~h}$ before assessing levels of target cell death as described in the legend of Fig. 6. The level of inhibition of target cell killing was determined by comparing the level of killing in the absence versus presence of CMA or $\alpha$ FasL for individual IEL samples with the mean value of 3-4 samples represented by the horizontal bar. ${ }^{*} \mathrm{p}<0.05$.

the intestinal immune system in general on tumorigenesis. By surveying IELs in $A p c^{M i n /+}$ mice during adenoma development we have identified modifications in both IEL numbers and cytotoxicity. In addition, we show that the absence of $\alpha \beta$ or $\gamma \delta$ T-cells significantly reduces adenoma number in the small intestine in the $\mathrm{Apc}^{\mathrm{Min} / \mathrm{+}}$ model. This suggests that altered T-cell populations and/or function play a role in promoting intestinal tumorigenesis in $\mathrm{Apc}^{\mathrm{Min/+}}$ mice, potentially by lack of immune surveillance and or microenvironmental changes.

The absence of similar differences in the distal small intestine may be due to the increased length of villi in the ileum of $A p c^{\mathrm{Min} /+}$ mice (39). IELs depleted to the greatest extent were type a IELs $\left(\mathrm{TcR} \alpha \beta^{+} \mathrm{CD} 8 \alpha \beta^{+}\right.$and $\left.\mathrm{TcR} \alpha \beta^{+} \mathrm{CD} 4^{+}\right)$, which are of thymic origin and enter the gut via Peyer's patches (40). The changes in IEL subset composition occur after tumour initiation $(<14$ days) and sub-microscopic adenoma formation ( $\sim 30$ days) (5) and may not therefore be a causal factor in the initiation of tumour development. However, it is not known if $\mathrm{T}$ cell subsets function normally at this stage. IEL depletion may occur as a consequence of the thymic atrophy and lymphodepletion that occurs in $A p c^{\mathrm{Min} /+}$ mice (41) that collectively would reduce the number of thymically-derived IELs able to enter the gut. This may not however fully account for the reduced numbers of type $b\left(C D 8 \alpha \alpha^{+}, T c R \alpha \beta / \gamma \delta^{+}\right)$IELs in $A p c^{\mathrm{Min} /+}$ mice as the role of the thymus in their generation is less certain. Although significant numbers of type b IELs are present in athymic mice recent studies suggest that thymic agonist selection processes contribute to the differentiation and migration of CD8 $\alpha \alpha^{+}$, TcR $\alpha \beta^{+}$IELs (42).

The Wnt- $\beta$-catenin signalling pathway has a wellcharacterized role in $\mathrm{T}$ and $\mathrm{B}$ cell development $(43,44)$ and is necessary for haematopoietic maturation (45). Whatever the mechanism of IEL loss in $A p c^{M i n /+}$ mice, depletion or loss of epithelia-associated immune cells in $A p c^{M i n /+}$ mice appears to be restricted to $\alpha \beta$ and $\gamma \delta$ IELs as other cells that are found in the intestinal mucosa, such as B cells and Natural Killer 
$\left(\mathrm{NK} 1.1^{+}\right)$cells, are unaffected by the $A p c^{M i n /+}$ mutation. If, or how, the changes in $A p c^{\mathrm{Min} /+}$ IEL repertoire contribute to tumorigenesis is unclear although the reduction in IEL cytotoxic activity and change in cytotoxic pathway utilisation among residual IELs, with the switch from perforin-granzyme to Fas-FasL-mediated killing by IELs may have some functional consequences. It remains to be seen which IEL populations undergo a switch in killing mechanism and if it occurs in $\alpha \beta$ and $\gamma \delta$-deficient mice. In hepatocellular carcinoma the tumour microenvironment shows multiple immunosuppressive features including impaired capacity for production of perforin by $\mathrm{CD} 8^{+}$ cells (46). Additional mechanistic studies are required to fully elucidate the role of each cytolytic pathway in tumour surveillance and tumorigenesis and, if IELs in $A p c^{M i n /+}$ mice can kill the tumours they develop.

Lack of either $\alpha \beta$ and $\gamma \delta \mathrm{T}$ cells and IELs in $A p c^{\mathrm{Min} /+}$ mice results in decreased tumour multiplicity in the small intestine. This decrease is highest for $\alpha \beta$ T cells suggesting that in this model $\alpha \beta \mathrm{T}$ cells may promote tumorigenesis. The fact that there are fewer adenomas in the small intestine in the absence of $\gamma \delta \mathrm{T}$ cells also suggests that these cells may contribute to tumorigenesis in this model. Alternatively, the complex regulation and cross-talk between $\mathrm{T}$ cell populations may mean that the absence of a particular subset alters the function of remaining subsets potentially creating a more tumour suppressive environment, reducing adenoma number. The existence of IEL cross-talk is supported by IEL development studies demonstrating their interdependence on each other for their development. TcR $\beta^{-/-}$mice display impaired $\gamma \delta \mathrm{T}$ cell development whereas $T c R \delta^{-/-}$mice have reduced numbers of $\alpha \beta^{+} \mathrm{CD} 8 \alpha \beta^{+}$IELs and $T c R \delta^{-/} \beta_{2} \mathrm{~m}^{-/}$mice lacking both $\gamma \delta$ T-cells and $\beta_{2}$-microglobulin have elevated numbers of TcR $\alpha \beta^{+} \mathrm{CD} 8 \alpha \alpha^{+}$ IELs (47). In addition, $\alpha \beta$ T cells display altered behaviour and hyperactivity in the absence of $\gamma \delta \mathrm{T}$ cells with altered cytotoxicity of $\gamma \delta$ T cells in $T c R \beta^{-/-}$mice (48), consistent with the interdependency of $\gamma \delta$ and $\alpha \beta$ IELs. This may explain ineffective restriction of tumour growth and increased numbers of adenomas in $A p c^{\mathrm{Min} /+}$ mice lacking $\alpha \beta \mathrm{T}$ cells. The importance of $\gamma \delta \mathrm{T}$ cells in adenoma formation was apparent from the observation that $A p c^{\mathrm{Min} /+}$ mice with intact $\gamma \delta$ IEL populations but lacking $\alpha \beta$ IELs had significantly fewer tumours than mice that were deficient in $\gamma \delta$ IELs. These findings also reinforce the concept of $\alpha \beta$ and $\gamma \delta$ IELs performing non-overlapping roles within the intestinal mucosa, with $\alpha \beta$ IELs being important for immunity $(49,50)$ and $\gamma \delta$ T-cells contributing to epithelial homeostasis (51-53). Expression of NK-like molecules on non-MHC restricted $\gamma \delta$ T-cells including NKG2D which can recognise ligands on stressed and transformed epithelial cells $(27,28)$ is consistent with them being better equipped than $\alpha \beta$ IELs to influence intestinal epithelial homeostasis.

In summary, this study describes for the first time changes in IEL repertoire and function in $\mathrm{Apc}^{\mathrm{Min/+}}$ mice and shows that the absence of either $\gamma \delta$ or $\alpha \beta$ IELs impacts upon tumour development.

\section{Acknowledgements}

This work was funded in part by Cancer Research UK (LM, PJS and SRC) and Yorkshire Cancer Research (PLC and MHC). MAH was funded by the MRC (UK).

\section{References}

1. Moser AR, Pitot HC and Dove WF: A dominant mutation that predisposes to multiple intestinal neoplasia in the mouse. Science 247: 322-324, 1990.

2. Su LK, Kinzler KW, Vogelstein B, et al: Multiple intestinal neoplasia caused by a mutation in the murine homolog of the APC gene. Science 256: 668-670, 1992.

3. Gregorieff A and Clevers $\mathrm{H}$ : Wnt signaling in the intestinal epi thelium: from endoderm to cancer. Genes Dev 19: 877-890, 2005.

4. Nusse R: Wnt signaling in disease and in development. Cell Res 15: 28-32, 2005.

5. Paulsen JE, Steffensen IL, Namork E, Eide TJ and Alexander J: Age-dependent susceptibility to azoxymethane-induced and spontaneous tumorigenesis in the Min/+ mouse. Anticancer Res 23: 259-265, 2003.

6. Shoemaker AR, Moser AR, Midgley CA, Clipson L, Newton MA and Dove WF: A resistant genetic background leading to incomplete penetrance of intestinal neoplasia and reduced loss of heterozygosity in Apc(Min/+) mice. Proc Natl Acad Sci USA 95: 10826-10831, 1998.

7. Moser AR, Dove WF, Roth KA and Gordon JI: The Min (multiple intestinal neoplasia) mutation-its effect on gut epithelial-cell differentiation and interaction with a modifier system. J Cell Biol 116: 1517-1526, 1992.

8. Dietrich WF, Lander ES, Smith JS, et al: Genetic identification of Mom-1, a major modifier locus affecting Min-induced intestinal neoplasia in the mouse. Cell 75: 631-639, 1993.

9. Silverman KA, Koratkar R, Siracusa LD and Buchberg AM: Identification of the modifier of Min 2 (Mom2) locus, a new mutation that influences Apc-induced intestinal neoplasia. Genome Res 12: 88-97, 2002

10. Suraweera N, Robinson J, Volikos E, et al: Mutations within Wnt pathway genes in sporadic colorectal cancers and cell lines. Int J Cancer 119: 1837-1842, 2006.

11. Kwong LN, Shedlovsky A, Biehl BS, Clipson L, Pasch CA and Dove WF: Identification of Mom7, a novel modifier of Apc(Min/+) on mouse chromosome 18. Genetics 176: 1237-1244, 2007.

12. Wilding J, Straub J, Bee J, et al: Cyclin D1 is not an essential target of beta-catenin signaling during intestinal tumorigenesis, but it may act as a modifier of disease severity in multiple intestinal neoplasia (Min) mice. Cancer Res 62: 4562-4565, 2002.

13. Dove WF, Clipson L, Gould KA, et al: Intestinal neoplasia in the ApcMin mouse: independence from the microbial and natural killer (beige locus) status. Cancer Res 57: 812-814, 1997.

14. Dudley ME, Sundberg JP and Roopenian DC: Frequency and histological appearance of adenomas in multiple intestinal neoplasia mice are unaffected by severe combined immunodeficiency (scid) mutation. Int J Cancer 65: 249-253, 1996.

15. Bouhnik Y, Vahedi K, Achour L, et al: Short-chain fructooligosaccharide administration dose-dependently increases fecal bifidobacteria in healthy humans. J Nutr 129: 113-116, 1999.

16. Howard MD, Gordon DT, Garleb KA and Kerley MS: Dietary fructooligosaccharide, xylooligosaccharide and gum arabic have variable effects on cecal and colonic microbiota and epithelial cell proliferation in mice and rats. J Nutr 125: 2604-2609, 1995.

17. Pierre F, Perrin P, Champ M, Bornet F, Meflah K and Menanteau J: Short-chain fructo-oligosaccharides reduce the occurrence of colon tumors and develop gut-associated lymphoid tissue in Min mice. Cancer Res 57: 225-228, 1997.

18. Pierre F, Perrin P, Bassonga E, Bornet F, Meflah K and Menanteau J: T cell status influences colon tumor occurrence in min mice fed short chain fructo-oligosaccharides as a diet supplement. Carcinogenesis 20: 1953-1956, 1999.

19. Forest V, Pierre F, Bassonga E, Meflah K and Menanteau J: Large intestine intraepithelial lymphocytes from $\mathrm{Apc}^{+/+}$and $\mathrm{Apc}^{+\mathrm{Min}}$ mice and their modulation by indigestible carbohydrates: the IL-15/IL-15R alpha complex and $\mathrm{CD} 4{ }^{+} \mathrm{CD} 25^{+} \mathrm{T}$ cells are the main targets. Cancer Immunol Immunother 54: 78-86, 2005.

20. Erdman SE and Poutahidis T: Roles for inflammation and regulatory T cells in colon cancer. Toxicol Pathol 38: 76-87, 2010.

21. Erdman SE, Sohn JJ, Rao VP, et al: $\mathrm{CD} 4{ }^{+} \mathrm{CD} 25^{+}$regulatory lymphocytes induce regression of intestinal tumors in Apc $\mathrm{An}^{\mathrm{Min} /+}$ mice. Cancer Res 65: 3998-4004, 2005.

22. Cheroutre H and Kronenberg M: Mucosal T lymphocytespeacekeepers and warriors. Springer Semin Immunopathol 27: 147-165, 2005. 
23. van Wijk $\mathrm{F}$ and Cheroutre $\mathrm{H}$ : Intestinal $\mathrm{T}$ cells: facing the mucosal immune dilemma with synergy and diversity. Semin Immunol 21: 130-138, 2009.

24. Rocha B, Vassalli P and Guy-Grand D: The V beta repertoire of mouse gut homodimeric alpha $\mathrm{CD} 8^{+}$intraepithelial $\mathrm{T}$ cell receptor alpha/beta + lymphocytes reveals a major extrathymic pathway of T cell differentiation. J Exp Med 173: 483-486, 1991

25. Suzuki H, Jeong KI, Okutani T and Doi K: Regional variations in the distribution of small intestinal intraepithelial lymphocytes in three inbred strains of mice. J Vet Med Sci 62: 881-887, 2000.

26. Hayday A, Theodoridis E, Ramsburg E and Shires J: Intraepithelial lymphocytes: exploring the Third Way in immunology. Nat Immunol 2: 997-1003, 2001.

27. Groh V, Steinle A, Bauer S and Spies T: Recognition of stressinduced MHC molecules by intestinal epithelial gammadelta T cells. Science 279: 1737-1740, 1998.

28. Groh V, Rhinehart R, Secrist H, Bauer S, Grabstein KH and Spies T: Broad tumor-associated expression and recognition by tumor-derived gamma delta T cells of MICA and MICB. Proc Natl Acad Sci USA 96: 6879-6884, 1999.

29. Van Kaer L, Wu M, Ichikawa Y, et al: Recognition of MHC TL gene products by gamma delta T cells. Immunol Rev 120: 89-115, 1991.

30. Cerwenka A and Lanier LL: NKG2D ligands: unconventional MHC class I-like molecules exploited by viruses and cancer. Tissue Antigens 61: 335-343, 2003.

31. Ke Y, Kapp LM and Kapp JA: Inhibition of tumor rejection by gammadelta T cells and IL-10. Cell Immunol 221: 107-114, 2003.

32. Seo N, Tokura Y, Takigawa M and Egawa K: Depletion of IL-10- and TGF-beta-producing regulatory gamma delta T cells by administering a daunomycin-conjugated specific monoclonal antibody in early tumor lesions augments the activity of CTLs and NK cells. J Immunol 163: 242-249, 1999.

33. Kettunen HL, Kettunen AS and Rautonen NE: Intestinal immune responses in wild-type and $\mathrm{Apc}^{\mathrm{Min} /+}$ mouse, a model for colon cancer. Cancer Res 63: 5136-5142, 2003.

34. Scott DJ, Hull MA, Cartwright EJ, et al: Lack of inducible nitric oxide synthase promotes intestinal tumorigenesis in the Apc(Min/+) mouse. Gastroenterology 121: 889-899, 2001.

35. Corazza N, Muller S, Brunner T, Kagi D and Mueller C: Differential contribution of Fas- and perforin-mediated mechanisms to the cell-mediated cytotoxic activity of naive and in vivo-primed intestinal intraepithelial lymphocytes. J Immunol 164: 398-403, 2000.

36. Guy-Grand D, Griscelli $C$ and Vassalli P: The mouse gut $T$ lymphocyte, a novel type of $\mathrm{T}$ cell. Nature, origin, and traffic in mice in normal and graft-versus-host conditions. J Exp Med 148: 1661-1677, 1978

37. Haigis KM, Hoff PD, White A, Shoemaker AR, Halberg RB and Dove WF: Tumor regionality in the mouse intestine reflects the mechanism of loss of Apc function. Proc Natl Acad Sci USA 101: 9769-9773, 2004.

38. Mehl KA, Davis JM, Clements JM, Berger FG, Pena MM and Carson JA: Decreased intestinal polyp multiplicity is related to exercise mode and gender in $\mathrm{Apc}^{\mathrm{Min} /+}$ mice. J Appl Physiol 98: 2219-2225, 2005.
39. You S, Ohmori M, Pena MM, et al: Developmental abnormalities in multiple proliferative tissues of Apc(Min/+) mice. Int J Exp Pathol 87: 227-236, 2006.

40. Cheroutre H: IELs: enforcing law and order in the court of the intestinal epithelium. Immunol Rev 206: 114-131, 2005.

41. Coletta PL, Muller AM, Jones EA, et al: Lymphodepletion in the $\mathrm{Apc}^{\mathrm{Min} /+}$ mouse model of intestinal tumorigenesis. Blood 103: 1050-1058, 2004.

42. Cheroutre H and Lambolez F: Doubting the TCR coreceptor function of CD8alpha alpha. Immunity 28: 149-159, 2008.

43. Verbeek S, Izon D, Hofhuis F, et al: An HMG-box-containing T-cell factor required for thymocyte differentiation. Nature 374 : 70-74, 1995.

44. Reya T, O'Riordan M, Okamura R, et al: Wnt signaling regulates B lymphocyte proliferation through a LEF-1 dependent mechanism. Immunity 13: 15-24, 2000.

45. Kirstetter P, Anderson K, Porse BT, Jacobsen SE and Nerlov C: Activation of the canonical Wnt pathway leads to loss of hematopoietic stem cell repopulation and multilineage differentiation block. Nat Immunol 7: 1048-1056, 2006.

46. Pang YL, Zhang HG, Peng JR, et al: The immunosuppressive tumor microenvironment in hepatocellular carcinoma. Cancer Immunol Immunother 58: 877-886, 2009.

47. Fujiura Y, Kawaguchi M, Kondo Y, et al: Development of CD8 alpha alpha ${ }^{+}$intestinal intraepithelial $\mathrm{T}$ cells in beta 2-microglobulin- and/or TAP1-deficient mice. J Immunol 156: 2710-2715, 1996.

48. Kaufmann SH, Blum C and Yamamoto S: Crosstalk between alpha/beta $\mathrm{T}$ cells and gamma/delta $\mathrm{T}$ cells in vivo: activation of alpha/beta T-cell responses after gamma/delta T-cell modulation with the monoclonal antibody GL3. Proc Natl Acad Sci USA 90: 9620-9624, 1993.

49. Bandeira A, Mota-Santos T, Itohara S, et al: Localization of gamma/delta $\mathrm{T}$ cells to the intestinal epithelium is independent of normal microbial colonization. J Exp Med 172: 239-244, 1990.

50. Guy-Grand D, Pardigon N, Darche S, Lantz O, Kourilsky P and Vassalli P: Contribution of double-negative thymic precursors to CD8alpha alpha (+) intraepithelial lymphocytes of the gut in mice bearing TCR transgenes. Eur J Immunol 31: 2593-2602, 2001.

51. Chen Y, Chou K, Fuchs E, Havran WL and Boismenu R: Protection of the intestinal mucosa by intraepithelial gamma delta T cells. Proc Natl Acad Sci USA 99: 14338-14343, 2002.

52. Komano H, Fujiura Y, Kawaguchi M, et al: Homeostatic regulation of intestinal epithelia by intraepithelial gamma delta T cells. Proc Natl Acad Sci USA 92: 6147-6151, 1995.

53. Yang H, Antony PA, Wildhaber BE and Teitelbaum DH: Intestinal intraepithelial lymphocyte gamma delta-T cell-derived keratinocyte growth factor modulates epithelial growth in the mouse. J Immunol 172: 4151-4158, 2004. 